\title{
Comparative evaluation of the immunodominant proteins of Brucella abortus for the diagnosis of cattle brucellosis
}

\author{
Mohandoss Nagalingam $^{1}$ (D), Thaslim J. Basheer ${ }^{1}$ (D), Vinayagamurthy Balamurugan ${ }^{1}$ (D), Rajeswari Shome ${ }^{1}$ (D),

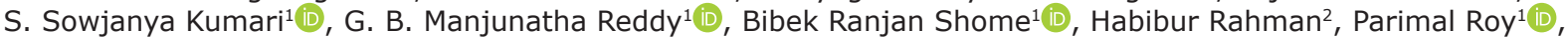 \\ J. Joseph Kingston ${ }^{3}$ and R. K. Gandham ${ }^{4}$ i
}

1. ICAR-National Institute of Veterinary Epidemiology and Disease Informatics, Bengaluru, Karnataka, India;

2. International Livestock Research Institute, New Delhi, India; 3. Defense Food Research Laboratory, Mysore, Karnataka, India; 4. National Institute of Animal Biotechnology, Hyderabad, Telangana, India.

Corresponding author: Mohandoss Nagalingam: nagar75@gmail.com

Co-authors: TJB: thaslimjb@gmail.com, VB: balavirol@gmail.com, RS: rajeswarishome@gmail.com, SSK: sowjanya.kumaris@gmail.com, GBMR: gbmpatho@gmail.com, BRS: brshome@gmail.com, HR: hricar@gmail.com, PR: parimalroy580@gmail.com, JJK: josephkingston@yahoo.com, RKG: gandham71@gmail.com

Received: 28-05-2020, Accepted: 15-02-2021, Published online: 30-03-2021

doi: www.doi.org/10.14202/vetworld.2021.803-812 How to cite this article: Nagalingam M, Basheer TJ, Balamurugan $V$, Shome R, Kumari SS, Reddy GBM, Shome BR, Rahman H, Roy P, Kingston JJ, Gandham RK (2021) Comparative evaluation of the immunodominant proteins of Brucella abortus for the diagnosis of cattle brucellosis, Veterinary World, 14(3): 803-812.

\begin{abstract}
Background and Aim: The present serodiagnosis of brucellosis in livestock is based on the whole cell or smooth lipopolysaccharide of the Brucella organism in which specificity is hampered by the cross-reactivity, especially with the antibodies against Yersinia enterocolitica O:9 organism. The problem can be addressed by screening for better immunodominant antigens. Hence, the present study was undertaken to screen protein antigens of Brucella abortus for their diagnostic potential in cattle brucellosis.
\end{abstract}

Materials and Methods: Protein antigens of B. abortus $(\mathrm{n}=10)$ non-reactive to antibodies against Y. enterocolitica O:9 were selected, expressed in Escherichia coli, assessed the reactivity of expressed recombinant proteins by Western blot, standardized indirect-enzyme-linked immunosorbent assay (ELISA) for detecting Brucella antibodies in cattle serum, and comparative evaluation was done.

Results: All the selected protein antigens were expressed and in the Western blot with Brucella antibodies positive cattle serum, six recombinant (Brucella protein 26 [BP26], Cu-Zn Superoxide dismutase [SodC], B. abortus I-1885, Serine protease, Bacterioferritin, and Brucella Lumazine Synthase [BLS]) proteins showed reaction whereas none of the proteins showed reactivity with Brucella negative cattle serum. ELISA has been done using known Brucella positive and negative cattle sera samples ( $\mathrm{n}=113$ each) in which the performance of recombinant proteins in diagnosing brucellosis was in the order of BP26 $>$ BLS $>$ SodC followed by rest of the proteins. BP26 based ELISA was found to be better with area under the curve as 0.953 , and diagnostic sensitivity, diagnostic specificity, and Youden's index of 90.27\%, 95.58\%, and 0.8584, respectively, with the excellent agreement $(\mathrm{k}=0.85)$.

Conclusion: BP26 could be a potential diagnostic antigen among the immunodominant proteins of B. abortus in ruling out $Y$. enterocolitica $\mathrm{O}: 9$ infection while diagnosing brucellosis in cattle herds.

Keywords: Brucella abortus, Brucella lumazine synthase, Brucella protein26, cattle brucellosis, Cu-Zn superoxide dismutase, Yersinia enterocolitica O:9.

\section{Introduction}

Brucellosis is a multifaceted zoonotic disease with significant animal and human health impact, caused by facultative, intracellular bacteria of genus Brucella, which comprises six main species, namely Brucella abortus, Brucella melitensis, Brucella suis, Brucella ovis, Brucella canis, and Brucella neotomae, and other recently identified species include Brucella pinnipedialis, Brucella ceti, Brucella microti, Brucella inopinata, Brucella papionis, and Brucella vulpis [1].

Copyright: Nagalingam, et al. Open Access. This article is distributed under the terms of the Creative Commons Attribution 4.0 International License (http://creativecommons.org/licenses/ by/4.0/), which permits unrestricted use, distribution, and reproduction in any medium, provided you give appropriate credit to the original author(s) and the source, provide a link to the Creative Commons license, and indicate if changes were made. The Creative Commons Public Domain Dedication waiver (http:// creativecommons.org/publicdomain/zero/1.0/) applies to the data made available in this article, unless otherwise stated.
The disease is usually represented by abortion, reduced fertility, and reduced milk production in ruminants. The common species involved in causing brucellosis in cattle is $B$. abortus.

Since the discovery of the brucellosis, the conventional serological tests, namely, Rose Bengal plate test (RBPT), standard tube agglutination test (SAT), enzyme-linked immunosorbent assay (ELISA), and complement fixation tests which utilize the whole Brucella cell and/or its smooth lipopolysaccharide (S-LPS) fractions are being used in diagnosis [2]. Cross-reactivity arises due to the resemblance of Brucella O-polysaccharide, a component of LPS with corresponding epitopes of Yersinia enterocolitica O:9, Salmonella urbana group N, Vibrio cholerae, Francisella tularensis, Escherichia coli O157, and Stenotrophomonas maltophilia [3]. In particular, serological interference induced by $Y$. enterocolitica $0: 9$ 
has complicated the eradication of brucellosis in some European countries such as France, Belgium, United Kingdom [4,5] with the prevalence of $Y$. enterocolitica ranging from $18 \%$ to $58 \%$ in cattle [6]. In European Union, $15 \%$ of the herds in regions free from brucellosis were infected with $Y$. enterocolitica $0: 9$ [7]. After 1990, the isolation of $Y$. enterocolitica O:9 from cattle has become a regular phenomenon not only from European Union but also from other parts of the world including New Zealand [8]. As diagnosis plays a key role in disease control/eradication programs, there is a strong need for tests that can avoid cross-reactivity, in particular against $Y$. enterocolitica $\mathrm{O}: 9$. This can be overcome by screening antigens other than surface antigens like S-LPS. Various proteins of Brucella spp. have been investigated for their use as a diagnostic antigen, replacing S-LPS either in the form of the purified native protein(s) or synthesized recombinant protein(s). Different proteins were reported from different research groups for their capacity in diagnosis; however, still, there is a scope for further screening.

The present study was aimed to screen better protein antigens for diagnosing cattle brucellosis which is void of cross-reactivity, especially against antibodies of $Y$. enterocolitica O:9. ELISA was done with these antigens and different cattle sera samples and compared for better performance. To the best of our knowledge, it is the first study comparing ten recombinant proteins that are non-reactive to $Y$. enterocolitica $0: 9$.

\section{Materials and Methods \\ Ethical approval}

The Institute Biosafety committee approval (F. No. 6-52/NIVEDI/Biosafety/2016/07-19 dtd.11.12.2017) was obtained for the work.

\section{Study period and location}

The work was conducted at ICAR-NIVEDI from January 2016 to March 2018. The cattle sera were collected from Karnataka, India.

\section{Bacterial strains, vectors, and serum}

B. abortus Strain 99 (NCTC 11363) procured from Indian Council of Agricultural Research Institute (ICAR)-Indian Veterinary Research Institute, Izatnagar, India, was used to obtaining deoxyribonucleic acid (DNA). HI-Control 10G and HI-Control BL21 (DE3) chemically competent cells with pETite $\mathrm{N}$-His Kan Vector (M/s Lucigen, USA) were used in this study for expression of proteins in E. coli system. Hyperimmune serum raised against $B$. abortus S99 and Y. enterocolitica O:9 in rabbit, rabbit serum tested negative for Brucella antibodies, and serum samples collected from different cattle were used in this study. The reference DNA sequence of $B$. abortus biovar 1 strain 9-941 was used for designing primers, comparison of amplified sequences, etc., The NCBI reference number for chromosome 1 is NC_006932 (2124241 bp) and that of chromosome 2 (1162204 bp) is NC_006933.
Selection of immunodominant proteins/protein antigens for expression

The immunodominant proteins were identified based on a literature survey concerning their reactivity with Brucella positive serum and non-reactivity with $Y$. enterocolitica O:9 positive serum. They include $\mathrm{Cu}-\mathrm{Zn}$ superoxide dismutase (SodC), Serine protease, BAB1-1885, Twin arginine translocation pathway signal sequence domain-containing protein (Twin arginine), Brucella protein26 (BP26), Solute-binding family 5 protein, Leu/Ile/Val-binding family protein, Branched-chain amino-acid ABC transporter substrate-binding protein, Thiamine transporter binding protein, Invasion protein B (InvB), Brucella lumazine synthase (BLS), bacterioferritin (Bfr), malate dehydrogenase (Mdh), VirB12, and Aldehyde dehydrogenase. The selected proteins are outer membrane or periplasmic except for BLS, Bfr, Mdh, VirB12, and Aldehyde dehydrogenase which are cytoplasmic proteins. These identified proteins were further checked through BLASTP for amino acid sequence identity and those showing $\leq 60 \%$ with other cross-reacting pathogens were selected for further expression (Table-1).

\section{Expression of immunodominant proteins}

The primers were designed for the selected gene sequences to suit enzyme-free cloning in the pETite $\mathrm{N}$-His Kan vector (Table-2). The respective gene sequences of selected proteins were amplified by PCR with reaction mixture comprising of $10 \times$ PCR buffer- $5 \mu \mathrm{L}$; forward and reverse primers $10 \mu \mathrm{M}$ each $1 \mu \mathrm{L}$; dNTP $(10 \mathrm{mM})-1 \mu \mathrm{L} ;$ B. abortus $\mathrm{S} 99$ template DNA $2 \mu \mathrm{L}(94 \mathrm{ng})$; high fidelity Taq polymerase $0.5 \mu \mathrm{L}(\mathrm{M} / \mathrm{s}$. Thermo Scientific, USA); and nuclease-free water were added to make up $50 \mu \mathrm{L}$. PCR was performed in the thermal cycler (M/s. Eppendorf, Germany) with the cycling conditions as mentioned in Table-2. The amplified product was run on $1.5 \%$ agarose gel containing ethidium bromide $(0.5 \mu \mathrm{g} / \mathrm{mL})$, visualized and documented in UV trans-illuminator.

The PCR amplicons were individually transformed with $\mathrm{pETite} \mathrm{N}$-His Kan vector into HI-Control $10 \mathrm{G}$ chemically competent cells, respectively, and recombinant colonies obtained were screened by colony PCR. The plasmids were extracted from the positive clones and double pass sequencing of plasmid DNA was carried out commercially (M/s. Eurofins, India) by vector-specific primers. After confirmation by sequencing, pETite N-His Kan vectors containing gene insert were individually transformed into HI-Control BL21 (DE3) and confirmed by colony PCR. The recombinant pETite N-His Kan BL21 clones were induced with IPTG for expression. The expression was optimized for the incubation time (1-5 h after induction) and IPTG concentration $(0.5-2.0 \mathrm{mM})$. The expressed proteins were characterized by SDS-PAGE and purified with Ni-NTA purification system and subsequently dialyzed. The Western blot was carried out with rabbit negative and hyperimmune sera raised against $B$. abortus $\mathrm{S} 99$ antigen, $Y$. enterocolitica $\mathrm{O}: 9$ 


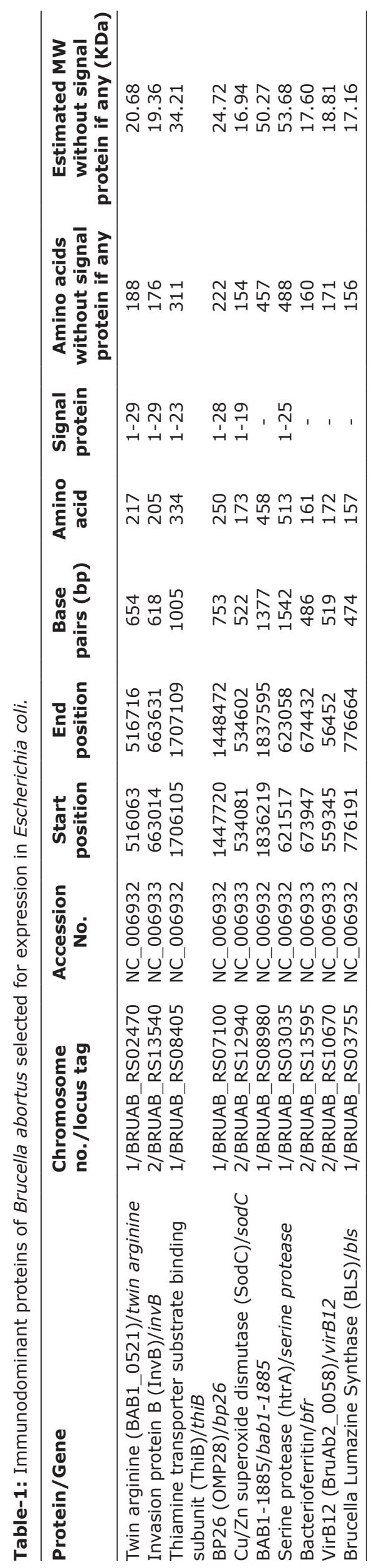

antigen, and cattle sera (positive and negative for Brucella antibodies confirmed by RBPT and Svanovir Indirect ELISA [Svanova, Sweden] for brucellosis).

\section{Selection of Brucella antibodies positive and nega-} tive cattle sera

A total of 573 cattle sera were collected both from brucellosis infected (abortions were common and $B$. abortus etiology established earlier) and non-infected farms (No abortion and B. abortus etiology absent) and none of the animals were vaccinated for brucellosis. The samples were screened by RBPT [9], Svanovir Indirect ELISA kit for brucellosis (Svanova, Sweden), and Svanovir Competitive ELISA kit for brucellosis (Svanova) following manufacturer instructions, and out of that 114 samples were positive by all the three tests/assays and 322 samples were negative by all the tests for Brucella antibodies. For establishing diagnostic sensitivity (DSe) and diagnostic specificity (DSp), a sample size of 113 positive and 113 negative sera from the above samples by all tests was selected for estimated DSe and DSp as $92 \%$, with an error margin of $5 \%$ at $95 \%$ confidence interval [10]. Further, the Brucella antibody titers were determined by the STAT/SAT [9]. The titer of selected positive sera from cattle ranged from 1 in 10 to 1 in 640 and hyperimmune serum from rabbit was having more than 1 in 2560 whereas all the negative sera were not having any titer. The negative samples were selected only from non-infected farms where no single positive reactor was present.

\section{Standardization of recombinant protein Indirect ELISA (I-ELISA)}

I-ELISA was standardized for antigen concentration and serum dilution by checkerboard titration using Brucella positive and negative serum samples. The recombinant proteins which have reacted in Western blot with cattle serum positive for Brucella antibodies were subjected individually for checkerboard titration for antigen concentration and serum dilution [11]. ELISA was done according to standard ELISA protocol. The recombinant proteins as antigen(s) were doubly diluted in a 96 well ELISA plate ranging from $16 \mu \mathrm{g}$ to $7.8 \mathrm{ng}$ along the row of the ELISA plate (Maxisorb, Nunc, Thermo Fisher Scientific, USA) in coating buffer (PBS-7.2 $\mathrm{pH}$ and kept overnight at $4^{\circ} \mathrm{C}$. The next day, the ELISA plate was incubated at $37^{\circ} \mathrm{C}, 150 \times \mathrm{g}$ for $1 \mathrm{~h}$. Further washing and blocking were done with wash buffer (PhosphateBuffered saline-Tween 20) and blocking buffer (5\% Skim Milk powder, 3\% Lactalbumin hydrolysate, and $0.1 \%$ Tween-20), respectively. For each antigen concentration Brucella positive and negative samples were titred along the column of the plate (1 in 100; 1 in 50; 1 in 25; and 1 in 12.5 in vertical directions). Further, blocked with blocking buffer for $1 \mathrm{~h}$ at $37^{\circ} \mathrm{C}$. After washing, conjugate (50 uL of 1:6000 dilution of horseradish peroxidase-conjugated anti-bovine $\mathrm{IgG}$ ) was added and incubated at $37^{\circ} \mathrm{C}$ for $1 \mathrm{~h}$. The reaction 
Table-2: List of designed oligonucleotides for amplification of gene sequences coding for selected immunodominant proteins of $B$. abortus and their size along with PCR cycling conditions.

\begin{tabular}{|c|c|c|c|c|c|c|}
\hline Gene & Primer* & Sequence $\left(5^{\prime}-3^{\prime}\right)^{\#}$ & $\begin{array}{l}\text { Primer start } \\
\text { position in } \\
\text { the gene } \\
\text { (bp) }\end{array}$ & $\begin{array}{l}\text { Primer } \\
\text { end } \\
\text { position in } \\
\text { the gene }\end{array}$ & $\begin{array}{l}\text { Amplicon } \\
\text { size }\end{array}$ & $\begin{array}{l}\text { Cycling } \\
\text { conditions for } \\
\text { PCR amplification }\end{array}$ \\
\hline \multirow[t]{2}{*}{$\begin{array}{l}\text { twin } \\
\text { arginine }\end{array}$} & $\mathrm{F}$ & $\begin{array}{l}\text { CAT CAT CAC CAC CAT CAC CAG } \\
\text { CAA CAC GCC CCG GAA G }\end{array}$ & \multirow[t]{2}{*}{88} & \multirow[t]{2}{*}{651} & \multirow[t]{2}{*}{564} & $\begin{array}{l}\text { 1. Initial } \\
\text { denaturation }\end{array}$ \\
\hline & $\mathrm{R}$ & $\begin{array}{l}\text { GTG GCG GCC GCT CTA TTA AAG } \\
\text { AGC GCT GTC GAT GAA TCC }\end{array}$ & & & & $\begin{array}{l}94^{\circ} \mathrm{C} \text { for } 3 \mathrm{~min} \\
\text { 2. Cycles }(\mathbf{n}=\mathbf{3 5})\end{array}$ \\
\hline \multirow[t]{2}{*}{$\operatorname{inv} B$} & $\mathrm{~F}$ & $\begin{array}{l}\text { CAT CAT CAC CAC CAT CAC CAG } \\
\text { CAG CCG CCG CAG GGT T }\end{array}$ & \multirow[t]{2}{*}{88} & \multirow[t]{2}{*}{615} & \multirow[t]{2}{*}{528} & $\begin{array}{l}\text { i. Denaturation: } \\
94^{\circ} \mathrm{C} \text { for } 1 \mathrm{~min}\end{array}$ \\
\hline & $\mathrm{R}$ & $\begin{array}{l}\text { GTG GCG GCC GCT CTA TTA TाT } \\
\text { GGC AGC GCC TाT TGC CTT }\end{array}$ & & & & $\begin{array}{l}\text { ii. Annealing: } \\
50-60^{\circ} \mathrm{C} \text { for }\end{array}$ \\
\hline \multirow[t]{2}{*}{ thiB } & $\mathrm{F}$ & $\begin{array}{l}\text { CAT CAT CAC CAC CAT CAC AAG } \\
\text { GAC AAG CTT ACT ATC TAT AC }\end{array}$ & \multirow[t]{2}{*}{70} & \multirow[t]{2}{*}{1002} & \multirow[t]{2}{*}{933} & $\begin{array}{l}1 \text { min. with } \\
\text { increment of } 1^{\circ} \mathrm{C}\end{array}$ \\
\hline & $\mathrm{R}$ & $\begin{array}{l}\text { GTG GCG GCC GCT CTA TTA TCT } \\
\text { GCT GGT GGC TGC CAG C }\end{array}$ & & & & $\begin{array}{l}\text { per cycle } \\
\text { iii. Extension: } 72^{\circ} \mathrm{C}\end{array}$ \\
\hline \multirow[t]{2}{*}{$b p 26$} & $\mathrm{~F}$ & $\begin{array}{l}\text { CAT CAT CAC CAC CAT CAC CAG } \\
\text { GAG AAT CAG ATG ACG ACG }\end{array}$ & \multirow[t]{2}{*}{85} & \multirow[t]{2}{*}{750} & \multirow[t]{2}{*}{666} & $\begin{array}{l}\text { for } 1 \text { min. for } \\
\text { genes less than }\end{array}$ \\
\hline & $\mathrm{R}$ & $\begin{array}{l}\text { GTG GCG GCC GCT CTA TTA CTT } \\
\text { GAT TTC AAA AAC GAC ATT GAC }\end{array}$ & & & & $\begin{array}{l}1 \mathrm{~Kb} \text { and } 72^{\circ} \mathrm{C} \\
\text { for } 2 \text { min. for }\end{array}$ \\
\hline \multirow[t]{2}{*}{ sodC } & $\mathrm{F}$ & $\begin{array}{l}\text { CAT CAT CAC CAC CAT CAC GAA } \\
\text { AGC ACG ACG GTA AAA ATG TAT G }\end{array}$ & \multirow[t]{2}{*}{58} & \multirow[t]{2}{*}{519} & \multirow[t]{2}{*}{462} & $\begin{array}{l}\text { genes more } \\
\text { than } 1 \mathrm{~Kb} \text {. }\end{array}$ \\
\hline & $\mathrm{R}$ & $\begin{array}{l}\text { GTG GCG GCC GCT CTA TTA TTC } \\
\text { GAT CAC GCC GCA GGC AAA AC }\end{array}$ & & & & $\begin{array}{l}\text { 3. Final extension } \\
72^{\circ} \mathrm{C} \text { for } 10 \mathrm{~min}\end{array}$ \\
\hline \multirow[t]{2}{*}{$B A B-1885$} & $\mathrm{~F}$ & $\begin{array}{l}\text { CAT CAT CAC CAC CAT CAC GCG } \\
\text { AAA TCC GGC ACC CCG }\end{array}$ & \multirow[t]{2}{*}{4} & \multirow[t]{2}{*}{1374} & \multirow[t]{2}{*}{1371} & \\
\hline & $\mathrm{R}$ & $\begin{array}{l}\text { GTG GCG GCC GCT CTA TTA CTG } \\
\text { ACC GGA AGA GGC CGG }\end{array}$ & & & & \\
\hline \multirow[t]{3}{*}{$\begin{array}{l}\text { serine } \\
\text { protease }\end{array}$} & $\mathrm{F}$ & $\begin{array}{l}\text { CAT CAT CAC CAC CAT CAC TTC } \\
\text { GTC GTA ACC GGC CCG }\end{array}$ & \multirow[t]{3}{*}{76} & \multirow[t]{3}{*}{1539} & \multirow[t]{3}{*}{1464} & \\
\hline & $\mathrm{R}$ & $\begin{array}{l}\text { GTG GCG GCC GCT CTA TTA TTC } \\
\text { CTG ATT GAT CGG CAG CG }\end{array}$ & & & & \\
\hline & $\mathrm{R}$ & $\begin{array}{l}\text { GTG GCG GCC GCT CTA TTA TTा } \\
\text { CAG CGA CGG AGC AAT AC }\end{array}$ & & & & \\
\hline \multirow[t]{2}{*}{ virB12 } & $\mathrm{F}$ & $\begin{array}{l}\text { CAT CAT CAC CAC CAT CAC CGC } \\
\text { ACA TTG GTT ATG GTC GC }\end{array}$ & \multirow[t]{2}{*}{4} & \multirow[t]{2}{*}{516} & \multirow[t]{2}{*}{513} & \\
\hline & $\mathrm{R}$ & $\begin{array}{l}\text { GTG GCG GCC GCT CTA TTA CTT } \\
\text { GCG TAA AAT TTC GAT ATC C }\end{array}$ & & & & \\
\hline \multirow[t]{2}{*}{ bfr } & $\mathrm{F}$ & $\begin{array}{l}\text { CAT CAT CAC CAC CAT CAC AAA } \\
\text { GGC GAA CCA AAG GTC ATC }\end{array}$ & \multirow[t]{2}{*}{4} & \multirow[t]{2}{*}{483} & 480 & \\
\hline & $\mathrm{R}$ & $\begin{array}{l}\text { GTG GCG GCC GCT CTA TTA CTC } \\
\text { AGC TTC GTC GGC GGG }\end{array}$ & & & & \\
\hline$b / s$ & $\mathrm{~F}$ & $\begin{array}{l}\text { CAT CAT CAC CAC CAT CAC AAC } \\
\text { CAA AGC TGT CCG AAC AAG AC }\end{array}$ & 4 & 474 & 471 & \\
\hline & $\mathrm{R}$ & $\begin{array}{l}\text { GTG GCG GCC GCT CTA TTA } \\
\text { GAC AAG CGC GGC GAT GCG }\end{array}$ & & & & \\
\hline
\end{tabular}

*F = Forward, $\mathrm{R}=$ Reverse, "Nucleotides in bold bind to the vector for enzyme free cloning

was visualized by adding substrate (o-phenylenediamine dihydrochloride $+30 \% \mathrm{H}_{2} \mathrm{O}_{2}$ ). Finally, the reaction was arrested using a stopping solution $(1 \mathrm{M}$ $\mathrm{H}_{2} \mathrm{SO}_{4}$ ). The OD was read at $492 \mathrm{~nm}$ by ELISA reader (Teccan, Switzerland).

\section{Evaluation of the suitability of recombinant protein I-ELISA}

After optimizing the antigen concentration and serum dilution, ELISA was carried out on 113 each Brucella antibodies positive and negative cattle sera.

\section{Statistical analysis}

Following standard definitions, a $2 \times 2$ contingency table and receiver operating characteristic (ROC) curve analysis were used to calculate all the diagnostic accuracy measures and confidence intervals based on OD values of the ELISA. The Youden's index was employed for the analysis. The accuracy measures were expressed as DSe and DSp. Fleiss kappa (К) statistics was used to assess the agreement between two tests, where a value of $\kappa>0.75$ is considered excellent, $\kappa=0.40-0.75$ is considered fair to good, and $\kappa<0.40$ is considered marginal to poor. $\mathrm{p}<0.05$ was considered statistically significant for proportional analyses.

For the ELISA which has shown higher DSe, DSp, and area under curve (AUC) with a particular antigen, percent positivity (PP) \{(Sample OD/Positive OD) $\times 100\}$ values were calculated. Further for the ELISA with the same antigen, other measures such as positive predictive value (PPV), negative predictive value (NPV), positive likelihood ratio, and negative likelihood ratio were calculated at different assumed prevalence levels $(5 \%, 10 \%$, and $20 \%)$. 
All the statistical analyses were carried out using MedCalc, version 17.7.2 (MedCalc Software Ltd, Belgium).

\section{Results}

Selection of immunodominant proteins for expression

Out of 15 proteins identified, ten proteins were selected further for expression. On BLASTP analysis, five proteins were eliminated due to their marked amino acid sequence identity $(>60 \%)$ with other pathogens (Table-3).

\section{Expression and characterization of immunodominant proteins}

DNA extracted from B. abortus S99 was used to successfully amplify the target genes (Figure-1), cloned into pETite N-His Kan vector, and transformed into competent HI-Control $10 \mathrm{G}$ cells. Plasmid extracted from overnight grown colonies of HI-Control 10G clones containing the respective gene inserts ranged from 102.7 to $191.1 \mathrm{ng} / \mu \mathrm{L}$ which were optimal in their concentration for further subjecting to sequencing. Sequencing by vector-specific primers revealed the nucleotide sequences of the respective insert gene. All the sequences have shown $100 \%$ identity with $B$. abortus bv. 1 str. 9-941 DNA sequence. After confirmation of sequence identity, the plasmids of pETite N-His Kan vector containing individual inserts of twin-arginine, inv $B$, thiB,$b p 26$, $\operatorname{sod} C$, bab-1885, serine protease, virB12, bfr, and bls, of the B. abortus S99 strain were successfully transformed into HI-Control BL21 (DE3) chemically competent cells, evident from the colony PCR with respective band size amplification for screened clones. The yield of the recombinant proteins ranged between 0.029 and $0.260 \mathrm{mg} / \mathrm{mL}$.

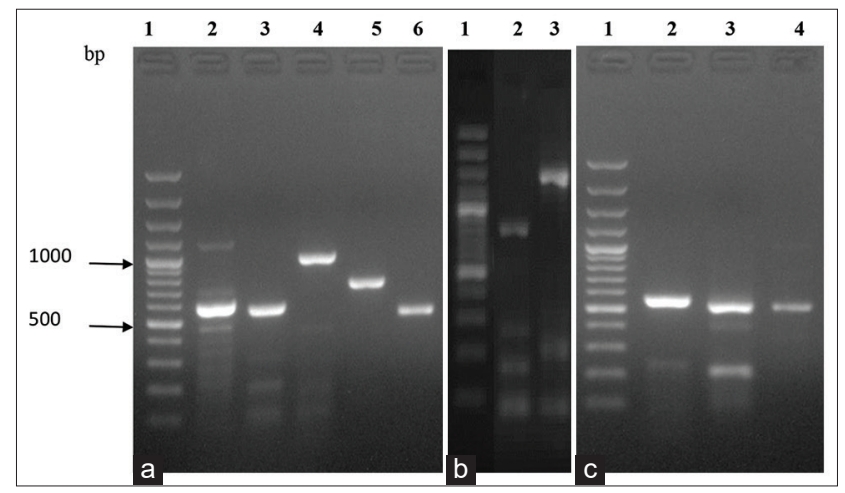

Figure-1: Agarose gel electrophoresis showing PCR amplicons of selected genes from Brucella abortus S99 DNA. (a) Lane 1: 100bp plus DNA ladder (Thermo Scientific); Lane 2: twin arginine gene (564 bp); Lane 3: invB gene (528 bp); Lane 4: thiB gene (933 bp); Lane 5: bp26 gene (666 bp); Lane 6: sodC gene (462 bp). (b) Lane 1: 100bp plus DNA ladder (Thermo Scientific);; Lane 2: bab-1885 gene (1371 bp); Lane 3: serine protease gene (1464 bp). (c) Lane 1: 100bp plus DNA ladder (Thermo Scientific); Lane 2: virB12 gene (513 bp); Lane 3: bfr gene (480 bp); Lane 4: bls gene (471 bp).

Table-3: Immunodominant proteins of Brucella abortus analyzed for identity by BLASTP.

\begin{tabular}{|c|c|c|c|c|c|c|c|c|}
\hline $\begin{array}{l}\text { S. } \\
\text { No. }\end{array}$ & Protein & $\begin{array}{c}\text { Yersinia } \\
\text { enterocolitica } \\
(\%)\end{array}$ & $\begin{array}{c}\text { Salmonella } \\
\text { enterica } \\
(\%)\end{array}$ & $\begin{array}{c}\text { Vibrio } \\
\text { cholerae } \\
(\%)\end{array}$ & $\begin{array}{l}\text { Francisella } \\
\text { tularensis } \\
(\%)\end{array}$ & $\begin{array}{c}\text { Escherichia } \\
\text { coli (\%) }\end{array}$ & $\begin{array}{c}\text { Stenotrophomonas } \\
\text { maltophilia (\%) }\end{array}$ & $\begin{array}{l}\text { Any other } \\
\text { identity } \\
\text { with other } \\
\text { pathogens (\%) }\end{array}$ \\
\hline 1. & SodC & 60 & 60 & 53 & 53 & 52 & 34 & - \\
\hline 2. & Serine protease & 39 & 39 & 41 & - & 37 & 39 & - \\
\hline 3. & BAB1-1885 & - & - & - & - & - & 60 & - \\
\hline 4. & Twin-arginine & & 26 & & & 27 & 26 & - \\
\hline 5. & BP26 & 29 & 28 & - & - & - & 41 & - \\
\hline 6. & $\begin{array}{l}\text { *Solute-binding } \\
\text { family } 5 \text { protein }\end{array}$ & 37 & 39 & 39 & 32 & 36 & - & $\begin{array}{l}\text { Haematobacter } \\
\text { sp. }(67 \%)\end{array}$ \\
\hline 7. & $\begin{array}{l}\text { *Leu/Ile/ } \\
\text { Val-binding } \\
\text { family protein }\end{array}$ & 23 & 23 & - & - & 23 & - & $\begin{array}{l}\text { Bordetella } \\
\text { bronchiseptica } \\
(76 \%)\end{array}$ \\
\hline 8. & $\begin{array}{l}\text { *Branched chain } \\
\text { amino-acid } A B C \\
\text { transporter } \\
\text { substrate-binding } \\
\text { protein }\end{array}$ & 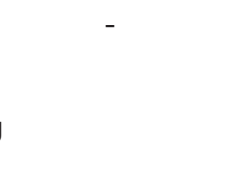 & 27 & - & - & - & - & $\begin{array}{l}\text { Bordetella sp. } \\
(62 \%)\end{array}$ \\
\hline 9. & $\begin{array}{l}\text { Thiamine } \\
\text { transporter }\end{array}$ & 52 & 58 & 51 & - & 58 & - & - \\
\hline & $\begin{array}{l}\text { Invasion } \\
\text { protein B }\end{array}$ & - & - & - & - & - & - & - \\
\hline & $\begin{array}{l}\text { Brucella } \\
\text { Lumazine } \\
\text { synthase }\end{array}$ & 38 & 56 & 32 & - & 51 & 34 & - \\
\hline 12. & Bacterioferritin & 50 & 52 & 52 & - & 52 & 54 & - \\
\hline 13. & $\begin{array}{l}\text { *Malate } \\
\text { dehydrogense }\end{array}$ & 33 & 32 & 30 & 64 & 39 & - & $\begin{array}{l}\text { Haematobacter } \\
\text { sp. }(77 \%)\end{array}$ \\
\hline 14. & VirB12 & - & 34 & - & - & 32 & 42 & - \\
\hline 15. & $\begin{array}{l}\text { *Aldehyde } \\
\text { dehydrogenase }\end{array}$ & 30 & 31 & 31 & 54 & 31 & 54 & $\begin{array}{l}\text { Bordetella } \\
\text { sp. }(69 \%)\end{array}$ \\
\hline
\end{tabular}

*Not selected for further expression. E values are less than 0; Sequence identity with Ochrobactrum sp. and Rhizobiales were not considered as they are generally soil organisms 
Western blot analysis of purified recombinant proteins with Brucella antibodies positive cattle serum has shown reactivity against BP26, SodC, BAB11885 , Serine protease, Bfr, and BLS proteins. Twin arginine, InvB, BP26, SodC, BAB1-1885, Serine protease, and BLS proteins reacted with B. abortus S99 antibodies positive rabbit serum. None of the proteins reacted with $Y$. enterocolitica O:9 antibodies positive rabbit serum, Brucella antibodies negative cattle and rabbit serum (Figures-2 and 3).

\section{Evaluation of the suitability of expressed proteins for the screening of cattle brucellosis}

The proteins which were reactive with Brucella antibodies positive cattle serum in Western blot were subjected to I-ELISA. The checkerboard titration revealed an optimum antigen concentration of $0.5 \mu \mathrm{g} /$ well for BP26, SodC, Bfr, Serine protease, $4 \mu \mathrm{g}$ for $\mathrm{BLS}$, and $8 \mu \mathrm{g}$ for BAB1-1885 and serum dilution of 1:50 irrespective of the antigens. ELISA with recombinant proteins BP26, SodC, BAB1-1885, Serine protease, $\mathrm{Bfr}$, and BLS in their optimized concentration with 113 Brucella antibodies positive and 113 negative field cattle serum samples and the ROC curve analysis revealed the cutoff along with DSe and DSp (Table-4). Considering all the proteins, BP26 based ELISA (Figure-4) has given a better AUC, DSe, and DSp, and hence PP values were calculated for ELISA with BP26 antigen which resulted in AUC of 0.953 (0.917-0.977), Youden index J of 0.8584, DSe of $90.27 \%$ and DSp of $95.58 \%$. The cutoff based on PP value is 10.187 and the indicators of validity and utility were presented in Table-5. The Kappa statistic revealed an excellent agreement of 0.850 (0.7810.918 at $95 \% \mathrm{CI}$ ) with the standard error of 0.0351 .

\section{Discussion}

In this study, an attempt was made to evaluate the suitability of immunodominant recombinant proteins that were not reactive to $Y$. enterocolitica $\mathrm{O}: 9$ antibodies for the diagnosis of cattle brucellosis. The immunoproteomics approach could be one of the efficient methods to identify specific immune-proteins among

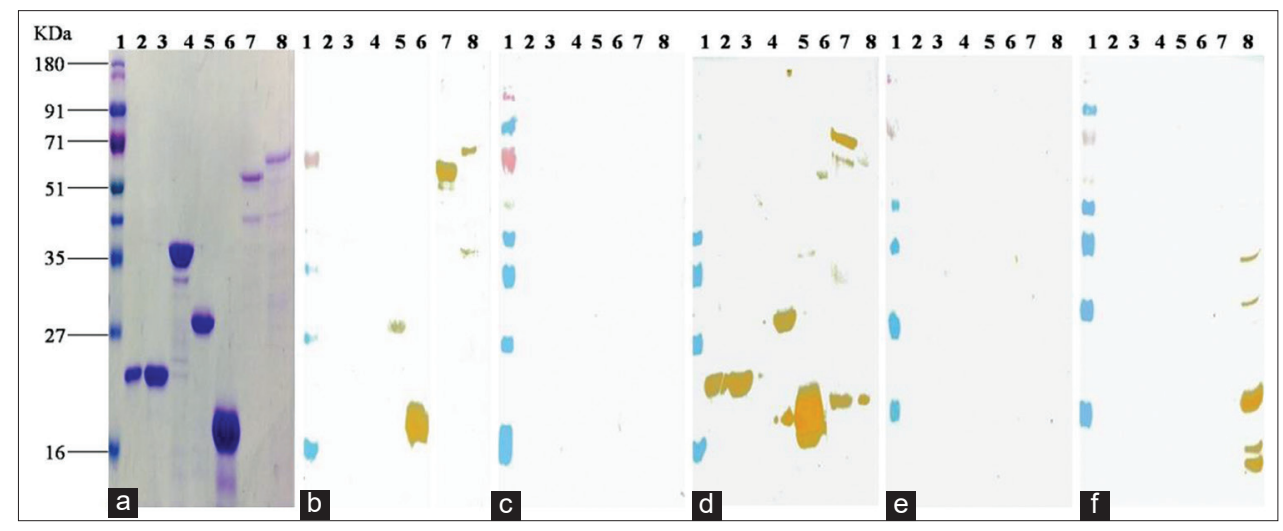

Figure-2: (a) SDS PAGE analysis of purified recombinant proteins. (b) Western blot analysis of purified recombinant proteins with Brucella antibodies positive cattle serum. (c) Western blot analysis of purified recombinant proteins with Brucella antibodies negative cattle serum. (d) Western blot analysis of purified recombinant proteins with Brucella S99 antibodies positive rabbit serum. (e) Western blot analysis of purified recombinant proteins with Brucella antibodies negative rabbit serum. (f) Western blot analysis of purified recombinant proteins with Yersinia enterocolitica 0:9 positive rabbit serum. Lane 1: Prestained marker; Lane 2: Twin arginine; Lane 3: Invasion B; Lane 4: Thiamine transporter; Lane 5: BP26; Lane 6: SodC; Lane 7: BAB1-1885; Lane 8: Serine protease.

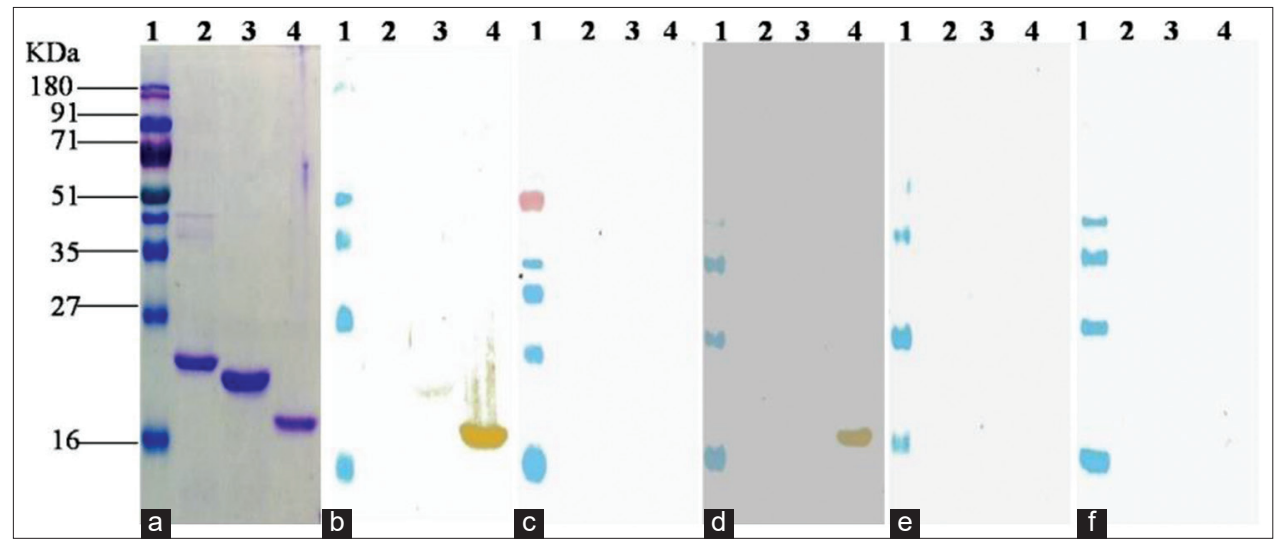

Figure-3: (a) SDS PAGE analysis of purified recombinant proteins. (b) Western blot analysis of purified recombinant proteins with Brucella antibodies positive cattle serum. (c) Western blot analysis of purified recombinant proteins with Brucella antibodies negative cattle serum. (d) Western blot analysis of purified recombinant proteins with Brucella S99 antibodies positive rabbit serum. (e) Western blot analysis of purified recombinant proteins with Brucella antibodies negative rabbit serum. (f) Western blot analysis of purified recombinant proteins with Yersinia enterocolitica 0:9 positive rabbit serum. Lane 1: Prestained marker; Lane 2:VirB12; Lane 3: Bfr; Lane 4: BLS. 
Table-4: DSe and DSp of various recombinant proteins based enzyme-linked immune sorbent assay for serodiagnosis of cattle brucellosis.

\begin{tabular}{lcccccccc}
\hline Antigen & \multicolumn{2}{c}{ DSe\% } & DSp\% & $\begin{array}{c}\text { Area under Standard Error } \\
\text { curve }\end{array}$ & \multicolumn{3}{c}{$\begin{array}{c}\text { 95 Confidence z statistic Significance Youden index J } \\
\text { interval }\end{array}$} \\
\hline rBP26 & 92.04 & 96.46 & 0.968 & 0.0111 & $0.936-0.987$ & 42.319 & $<0.0001$ & 0.8850 \\
rSodC & 76.11 & 57.52 & 0.676 & 0.0360 & $0.610-0.736$ & 4.869 & $<0.0001$ & 0.3363 \\
rBAB1-1885 & 54.87 & 69.91 & 0.603 & 0.0380 & $0.536-0.667$ & 2.706 & 0.0068 & 0.2478 \\
rHtrA & 54.87 & 62.83 & 0.599 & 0.0375 & $0.532-0.664$ & 2.641 & 0.0083 & 0.1770 \\
rBfr & 37.17 & 72.57 & 0.528 & 0.0385 & $0.461-0.595$ & 0.737 & 0.4608 & 0.09735 \\
rBLS & 82.30 & 65.49 & 0.750 & 0.0331 & $0.688-0.805$ & 7.564 & $<0.0001$ & 0.4779 \\
\hline
\end{tabular}

DSe: Diagnostic sensitivity, DSp: Diagnostic specificity

Table-5: Parameters of BP26 based ELISA for diagnosis of bovine brucellosis under various assumed prevalence level.

\begin{tabular}{|c|c|c|c|c|c|c|c|c|c|c|c|c|c|c|}
\hline $\begin{array}{l}\text { Assumed } \\
\text { prevalence } \\
(\%)\end{array}$ & DSe\% & CI\% & DSp\% & $\mathrm{CI} \%$ & AUC & CI & LR+ & CI & LR- & CI & PPV\% & CI\% & NPV\% & CI\% \\
\hline 5 & 90.27 & $\begin{array}{c}83.25 \\
\text { to } \\
95.04\end{array}$ & 94.69 & $\begin{array}{c}88.80 \\
\text { to } \\
98.03\end{array}$ & 0.92 & $\begin{array}{c}0.88 \\
\text { to } \\
0.96\end{array}$ & 17.00 & $\begin{array}{c}7.79 \\
\text { to } \\
37.12\end{array}$ & 0.10 & $\begin{array}{c}0.06 \\
\text { to } \\
0.18\end{array}$ & 47.22 & $\begin{array}{c}29.07 \\
\text { to } \\
66.14\end{array}$ & 99.46 & $\begin{array}{c}99.06 \\
\text { to } \\
99.69\end{array}$ \\
\hline 10 & 90.27 & $\begin{array}{c}83.25 \\
\text { to } \\
95.04\end{array}$ & 94.69 & $\begin{array}{c}88.80 \\
\text { to } \\
98.03\end{array}$ & 0.92 & $\begin{array}{c}0.88 \\
\text { to } \\
0.96\end{array}$ & 17.00 & $\begin{array}{c}7.79 \\
\text { to } \\
37.12\end{array}$ & 0.10 & $\begin{array}{c}0.06 \\
\text { to } \\
0.18\end{array}$ & 65.38 & $\begin{array}{c}46.38 \\
\text { to } \\
80.49\end{array}$ & 98.87 & $\begin{array}{c}98.03 \\
\text { to } \\
99.35\end{array}$ \\
\hline 20 & 90.27 & $\begin{array}{c}83.25 \\
\text { to } \\
95.04\end{array}$ & 94.69 & $\begin{array}{c}88.80 \\
\text { to } \\
98.03\end{array}$ & 0.92 & $\begin{array}{c}0.88 \\
\text { to } \\
0.96\end{array}$ & 17.00 & $\begin{array}{c}7.79 \\
\text { to } \\
37.12\end{array}$ & 0.10 & $\begin{array}{c}0.06 \\
\text { to } \\
0.18\end{array}$ & 80.95 & $\begin{array}{c}66.06 \\
\text { to } \\
90.27\end{array}$ & 97.49 & $\begin{array}{c}95.68 \\
\text { to } \\
98.56\end{array}$ \\
\hline
\end{tabular}

$\mathrm{DSe}=$ Diagnostic Sensitivity, DSp=Diagnostic Specificity, CI=Confidence interval, AUC=Area under curve, $\mathrm{LR}+=$ Positive Likelihood ratio, LR- =Negative Likelihood ratio, PPV=Positive predictive value, NPV=Negative predictive value

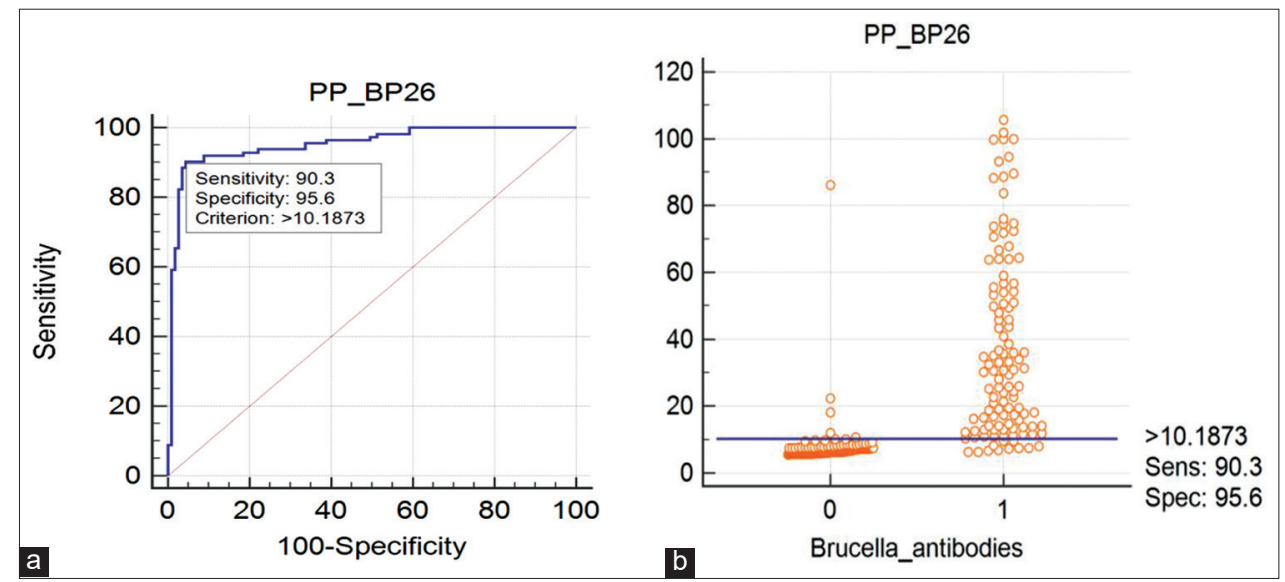

Figure-4: (a) ROC graph analysis of PP values of BP26 in ELISA with Brucella antibodies positive and negative cattle serum to optimize sensitivity and specificity. (b) Dot plot graph showing PP values of BP26 in ELISA with Brucella antibodies positive and negative cattle serum with cut off obtained from ROC curve analysis.

the greater range of proteins expressed by Brucella spp. [12]. Understanding the humoral immune response during Brucella infections will aid in the identification of immunogenic proteins. Appropriate identification and characterization of several immunoreactive proteins concerning seroreactivity can result in a satisfactory diagnostic test [13]. Although individual recombinant proteins have been described by many researchers for the diagnosis of brucellosis, a methodical way of comparing various immunodominant proteins and identification of best among them was undertaken in this study.

Using bovine sera, Ko et al. [14] identified immunodominant proteins of B. abortus 1119-3 strain, Kim et al. [15] identified that of B. abortus RB51 and
Lee et al. [16] identified that of B. abortus 544. Lee et al. [17] used mice sera for B. abortus 544. From these studies, 61 Brucella proteins which are reactive only with Brucella antibodies and not with any other cross-reacting antibodies, in particular antibodies of $Y$. enterocolitica O:9 were identified. Further with the criteria of the outer membrane proteins (OMPs) or periplasmic proteins as more quantity of antibodies is expected against OMPs, the list was narrowed down to 11 proteins. However, since Brucella is an intracellular organism, the host immune response is not restricted to surface proteins and cytoplasmic proteins can also induce a higher antibody response [18], other proteins that were documented earlier were also considered with the idea of not missing 
out the immunodominant proteins irrespective of OMP or cytosolic. Besides, proteins such as chaperonin GroEL, Ribosomal protein L7/L12, chaperonin GroES [12], and OMP25 [14] were not considered due to their reactivity with cross-reacting antibodies. Letesson et al. [18] reported that OMP10, OMP16, OMP19, OMP25, OMP36, p15, and p39 were not useful for detecting naturally infected cattle. Thus, a meticulous selection of immunodominant proteins of B. abortus was made and further narrowed down based on the sequence identity with other pathogens.

In the case of allergic proteins, a minimum $35 \%$ shared identity, plus a minimum of 80 amino acid overlap length, are the criteria to identify sequences that have potential cross-reactivity between an unknown and a known allergen [19]. SodC, an immunodominant Brucella protein identified by researchers [14-16] has shown non-reactivity with $Y$. enterocolitica $\mathrm{O}: 9$ antibodies even though the sequence identity with the organism is $60 \%$. Hence, in the case of proteins identified in this study, the identity threshold was fixed as $60 \%$ and above which if there is any sequence identity, those proteins were not considered further.

B. abortus strain 99 was used in this study as OIE recommends this strain [20] for the production of antigens for the diagnostic tests. Moreover, the amino acid sequences of proteins selected in this study are identical among various strains of $B$. abortus.

The selected proteins $(\mathrm{n}=10)$ were all expressed using pETite N-His Kan vector and as much of the earlier literature suggested that expression of BP26 and few other proteins leads to inclusion body formation, in this study directly after expression denaturing method of purification was carried out irrespective of whether the expressed proteins form inclusion bodies or not. There is a possibility for binding background contaminants under native conditions than under denaturing conditions and thus denaturing method of purification helped in yielding pure proteins. Cloeckaert et al. [21] observed a double band for $\mathrm{rBP} 26$ against infected sheep sera which could be due to the presence of both preprotein with its signal peptide and cleaved protein without signal peptide. The proteins in this study were expressed without signal sequences.

In Western blot, the additional reactivity of Twin arginine, InvB in rabbit hyperimmune serum compared to the cattle serum in this study might be due to the strong immune response in rabbits by use of adjuvants and frequent administration of killed antigen. The variations in the reactivity can be attributed to the differences like the serum used in the studies such as quantity and duration of exposure to the Brucella organism and stage of the infection. The observation of reactivity of Bfr only in cattle sera and not in rabbit hyperimmune serum needs to be explored further whether this reactivity occurs only in case of sera from infected and not from sera raised against the killed antigen. In addition, non-reactivity of these expressed antigens against $Y$. enterocolitica O:9 serum of rabbit confirms the right selection of candidate proteins for increasing the specificity of brucellosis diagnosis.

In absence of a gold standard, for the right classification of sera into Brucella antibodies positive and negative, a battery of tests/assays is required. Hence, in this study, RBPT, I-ELISA, and C-ELISA have been employed to select a panel of Brucella antibodies positive and negative sera for evaluating recombinant proteins. A test/assay with a high DSe is useful for "ruling out" a disease if an animal tests negative and a test with a high DSp is useful for "ruling in" a disease if an animal, tests positive. As LPS/whole antigen-based tests were more sensitive and less specific, the test which can contribute to more specificity and nominal sensitivity can provide additional information or can complement the existing test. In this study, the decreasing order of DSe was observed with BP26, BLS, SodC, BAB1885 , Serine protease, and Bfr based ELISA whereas the decreasing order of DSp was observed with BP26, Bfr, BAB-1885, BLS, and SodC based ELISA. DSe of $70.7 \%-80.5 \%$ and DSp of $84.6 \%-100 \%$ [7] DSe of $88.7 \%$, DSp of $93.8 \%$ [22], DSe of $96.7 \%$, and DSp of 95.4\% [23] in bovines were observed in ELISA based on BP26 antigen; whereas, in this study, DSe of $92.04 \%$ and DSp of $96.46 \%$ were observed. The differences in DSe and DSp from different studies may be attributed to differences in samples under study, the gold standard against which the test was compared apart from inherent changes in the test procedure adopted. Youden's index combines DSe and DSp and provides a single value for the comparison. Based on Youden's index the performance of the BP26 is superior which is followed by BLS, SodC, and the rest of the proteins.

The AUC, DSe, DSp, and Youden's index based on PP values of BP26 based ELISA were 0.953, $90.27 \%, 95.58 \%$, and 0.8584 as against based on OD values $0.968,92.04 \%, 96.46 \%$, and 0.8850 (Table-4), respectively. Although there is a marginal reduction in all the values based on PP values in comparison to OD values, the calculations based on PP values are more stable. As the DSe is $90.27 \%$, ruling in the individual animal may not be appropriate whereas it can be used as a test for detecting infected herds. PPV and NPV are both dependent on the prevalence of the disease and hence they were not calculated at the preliminary level of selection of the antigen because the number of positive and negative samples was pre-decided in the experiment and not indicative of prevalence level. Moreover, as PPV and NPV are dependent on prevalence, the values change concerning prevalence of the study area and not constant. Hence, AUC, DSe, DSp were considered in identifying the best antigen for ELISA as they do not vary with the prevalence level. However, PPV and NPV at assumed prevalence levels were calculated to assess the utility of the test. The NPV remains high and constant across various prevalence levels of $20 \%, 10 \%$, and $5 \%$ from $97.49 \%$ to $99.46 \%$ whereas PPV increases from $47.22 \%$ to $80.95 \%$ from low prevalence $(5 \%)$ to high prevalence 
(20\%). Furthermore, the LR provides a suitable summary measure, which is independent of prevalence.

BP26 is highly conserved in the genus Brucella, and the recombinant protein from one Brucella species might be used for the serological diagnosis of infections caused by all the Brucella species, provided that the animal host can induce an immune response against this antigen [24]. Letesson et al. [18] documented that antibody responses to proteins were found to be limited to animals that developed an active brucellosis infection and this can be validated further with BP26 ELISA to identify active shedders of Brucella organisms in a herd. In this study, one of the important cross-reacting organism which has created trouble in few of the countries of the world, namely, Y. enterocolitica O:9 was addressed through the selection of Brucella antibodies reacting recombinant proteins but not reacted to experimentally raised hyperimmune rabbit serum to $Y$. enterocolitica O:9. Further, the identified recombinant protein should also be checked against other cross-reacting antibodies to ensure maximum specificity.

\section{Conclusion}

As there are many claims for various recombinant proteins as the best recombinant proteins for diagnosing cattle brucellosis, this study has brought out the ranking and identified BP26 as the best suitable recombinant protein among them. BP26 based ELISA can be used as a screening test for detecting infected herds, to rule out cross-reactivity due to $Y$. enterocolitica $\mathrm{O}: 9$ in infected herds. It can also complement the existing diagnostic tests such as RBPT and sLPS based ELISA.

\section{Authors' Contributions}

MN conceived, designed, carried out the experiment, and wrote the draft of the manuscript. TJB and SSK assisted in carrying out the experiment. RS, GBMR, and JJK assisted in sample collection and other biological collection. $\mathrm{MN}$ and $\mathrm{VB}$ analyzed data. RKG, BRS, HR, and PR provided guidance and support to carry out the experiments. All authors read and approved the final manuscript.

\section{Acknowledgments}

The authors wish to thank the ICAR, New Delhi, India, for providing facilities, encouragement, and support. This research work is part of the $\mathrm{Ph} . \mathrm{D}$. program of the first author under ICAR-IVRI and ICAR-NIVEDI. The research project work was funded by the Department of Biotechnology (DBT), Government of India (F. No. DBT Network Project on Brucellosis/2012; 102/IFD/SAN/3142/2012-13 dated 27-09-2012).

\section{Competing Interests}

The authors declare that they have no competing interests.

\section{Publisher's Note}

Veterinary World remains neutral with regard to jurisdictional claims in published institutional affiliation.

\section{References}

1. Whatmore, A.M., Koylass, M.S., Muchowski, J., EdwardsSmallbone, J., Gopaul, K.K. and Perrett, L.L. (2016) Extended multilocus sequence analysis to describe the global population structure of the genus Brucella: Phylogeography and relationship to biovars. Front. Microbiol, 7: 2049.

2. Ducrotoy, M.J., Conde-Álvarez, R., Blasco, J.M. and Moriyón, I. (2016) A review of the basis of the immunological diagnosis of ruminant brucellosis. Vet. Immunol. Immunopathol., 171: 81-102.

3. Al Dahouk, S., Sprague, L.D. and Neubauer, H. (2013) New developments in the diagnostic procedures for zoonotic brucellosis in humans. Review. Rev. Sci. Tech., 32(1): 177-188.

4. Adone, R. and Pasquali, P. (2013) Epidemiosurveillance of brucellosis. Rev. Sci. Tech., 32(1): 199-205.

5. Hilbink, F., Fenwick, S.G., Thompson, E.J., Kittelberger, R., Penrose, M. and Ross, G.P. (1995) Non-specific seroreactions against Brucella abortus in ruminants in New Zealand and the presence of Yersinia enterocolitica 0:9. N. Z. Vet. J., 43(5): $175-178$.

6. Nagaraju, N.R., Isloor, S., Rao, S.M. and Rajasekhar, M. (2003) Seroprevalence of bovine yersiniosis in India. Indian J. Anim. Sci. 73(1): 48-50.

7. Munoz, P.M., Marin, C.M., Monreal D., Gonzalez, D., GarinBastuji, B., Diaz, R., Mainar-Jaime, R.C., Moriyon, I. and Blasco, J.M. (2005) Efficacy of several serological tests and antigens for diagnosis of bovine brucellosis in the presence of false-positive serological results due to Yersinia enterocolitica O:9. Clin. Diagn. Lab. Immunol., 12(1): 141-151.

8. Godfroid, J. and Kasbohrer, A. (2002) Brucellosis in the European Union and Norway at the turn of the twenty-first century. Vet. Microbiol., 90(1-4): 135-145.

9. Alton, G.G., Jones, L.M., Angus, R.D. and Verger, J.M. (1988) Techniques for the Brucellosis Laboratory. Institute National De La Recherche Agronomique, Paris, France.

10. World Organization for Animal Health (OIE). (2016) Principles and methods of validation of diagnostic assays for infectious diseases. In: Manual of Diagnostic Tests and Vaccines for Terrestrial Animals. Ch. 1.1.2. OIE, Paris. Available from: http://www.oie.int/fileadmin/home/eng/ health standards/aahm/current/chapitre validation diagnostics_assays.pdf. Retrieved on 25-08-2016.

11. Crowther, J.R. (2009) The ELISA Guidebook. Methods in Molecular Biology. $2^{\text {nd }}$ ed., Vol. 516. Humana Press, United States. p566.

12. Al Dahouk, S., Nockler, K., Scholz, H.C., Tomaso, H., Bogumil, R. and Neubauer, H. (2006) Immunoproteomic characterization of Brucella abortus 1119-3 preparations used for the serodiagnosis of Brucella infections. $J$. Immunol. Methods, 309(1-2): 34-47.

13. Pajuaba, A.C., Silva, D.A., Almeida, K.C., Cunha-Junior, J.P., Pirovani, C.P., Camillo, L.R. and Mineo, J.R. (2012) Immunoproteomics of Brucella abortus reveals differential antibody profiles between S19-vaccinated and naturally infected cattle. Proteomics, 12(6): 820-831.

14. Ko, K.Y., Kim, J.W., Her, M., Kang, S.I., Jung, S.C., Cho, D.H. and Kim, J.Y. (2012) Immunogenic proteins of Brucella abortus to minimize cross-reactions in brucellosis diagnosis. Vet. Microbiol., 156(3-4): 374-380.

15. Kim, J.Y., Sung, S.R., Lee, K., Lee, H.K., Kang, S.I., Lee, J.J., Jung, S.C., Park, Y.H. and Her, M. (2014) Immunoproteomics of Brucella abortus RB51 as candidate antigens in serological diagnosis of brucellosis. Vet. Immunol. Immunopathol., 160(3-4): 218-224.

16. Lee, J.J., Simborio, H.L., Reyes, A.W., Kim, D.G., 
Hop, H.T., Min, W., Her, M., Jung, S.C., Yoo, H.S. and Kim, S. (2014) Proteomic analyses of the time course responses of mice infected with Brucella abortus 544 reveal immunogenic antigens. FEMS Microbiol. Lett., 357(2): 164-174.

17. Lee, J.J., Simborio, H.L., Reyes, A.W., Kim, D.G., Hop, H.T., Min, W., Her, M., Jung, S.C., Yoo, H.S. and Kim, S. (2015) Immunoproteomic identification of immunodominant antigens independent of the time of infection in Brucella abortus 2308-challenged cattle. Vet. Res., 46: 17.

18. Letesson, J.J., Tiber, A., Van-Eynde, G., Wansard, V., Weynants, V., Denoel, P. and Saman, E. (1997) Humoral immune responses of Brucella-infected cattle, sheep and goats to eight purified recombinant Brucella proteins in an indirect enzyme-linked immunosorbent assay. Clin. Diagn. Lab. Immunol., 4(5): 556-564.

19. McClain, S. (2017) Bioinformatic screening and detection of allergen cross-reactive IgE-binding epitopes. Mol. Nutr. Food Res., 61(8): 1600676.

20. World Organization for Animal Health (OIE). (2016a) Brucellosis (Brucella abortus, B. melitensis and B. suis) (infection with $B$. abortus, $B$. melitensis and $B$. suis). In: Manual of Diagnostic Tests and Vaccines for Terrestrial
Animals. Ch. 2.1.4. OIE, Paris. Available from: http:// www.oie.int/fileadmin/home/eng/health_standards/ tahm/2.01.04_brucellosis.pdf. Retrieved on 27-01-2017.

21. Cloeckaert, A., Debbarh, H.S., Vizcaíno, N., Saman, E., Dubray, G. and Zygmunt, M.S. (1996) Cloning, nucleotide sequence, and expression of the Brucella melitensis bp26 gene coding for a protein immunogenic in infected sheep. FEMS Microbiol. Lett., 140(2-3): 139-144.

22. Chaudhuri, P., Prasad, R., Kumar, V. and Gangaplara, A. (2010) Recombinant OMP 28 antigen-based indirect ELISA for serodiagnosis of bovine brucellosis. Mol. Cell. Probes, 24(3): 142-145.

23. Lim, J.J., Kim, D.H., Lee, J.J., Kim, D.G., Min, W., Lee, H.J., Rhee, M.H., Chang, H.H. and Kim, S. (2012) Evaluation of recombinant $28 \mathrm{kDa}$ outer membrane protein of Brucella abortus for the clinical diagnosis of bovine brucellosis in Korea. J. Vet. Med. Sci., 74(6): 687-691.

24. Seco-Mediavilla, P., Verger, J.M., Grayon, M., Cloeckaert, G.A., Marín, C.M., Zygmunt, M.S., FernándezLago, L. and Vizcaíno, N. (2003) Epitope mapping of the Brucella melitensis BP26 immunogenic protein: Usefulness for diagnosis of sheep brucellosis. Clin. Diagn. Lab. Immunol., 10(4): 647-651. 